79th International Scientific Conference

University of Latvia

\title{
MATHEMATICAL METHODS FOR RESEARCH EXCELLENCE Book of Abstracts
}

Latvijas Universitätes

79. starptautiskā zinātniskā konference

Matemātiskās metodes pētijumu izcilībai

Tēžu krājums

Scientific

Conference of

the University

of Latvia

UNIVERSITY OF LATVIA FACULTY OF PHYSICS, MATHEMATICS AND OPTOMETRY 
University of Latvia. 79th International Scientific Conference, Mathematical Methods for Research Excellence: Book of Abstracts. Riga: University of Latvia, 2021. 17 Ipp.

The 79th International Scientific Conference of the University of Latvia.

Mathematical Methods for Research Excellence Section.

Book of Abstracts

Latvijas Universitātes 79. starptautiskā zinātniskā konference.

Matemātisko metožu pētījumu izcilībai sekcija.

Tēžu krājums

Tēžu krājums publicēts autoru redakcijā

Sastādītāja: Daiga Cepīte-Frišfelde

DOI: 10.22364/luszk.79.mmre.ab 

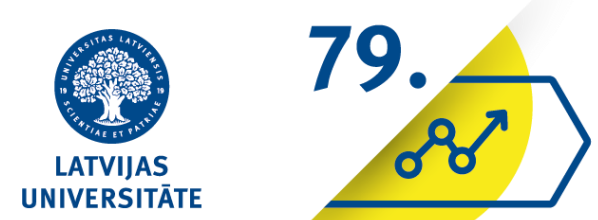

Latvijas

Universitātes

starptautiskā

zinātniskā

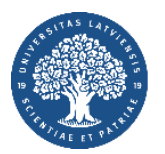

UNIVERSITY OF LATVIA

FACULTY OF PHYSICS,

MATHEMATICS

AND OPTOMETRY

konference

\title{
Matemātiskās metodes pētijumu izcilībai
}

\author{
Piektdiena, 2021. gada 29. janvāris plkst. 13:00 \\ attālināti Zoom platformā
}

\section{PROGRAMMA}

\begin{tabular}{|c|c|c|}
\hline \multicolumn{3}{|c|}{ Vadītājs/Chair: Dr.phys. Vadims Geža } \\
\hline $13.00-13.10$ & Atklāšana & \\
\hline $13.10-13.30$ & $\begin{array}{l}\text { Jānis Bajārs }^{1} \text {, J.Chris } \\
\text { Eilbeck }^{2}, \text { Benedict } \\
\text { Leimkuhler }^{3} \\
{ }^{1} \text { Latvijas Universitāte, }^{2} \text { Heriot-Watt University, } \\
{ }^{3} \text { The University of } \\
\text { Edinburgh }\end{array}$ & $\begin{array}{l}\text { Divu dimensiju nelineāru vịnnu izkliedēšanās } \\
\text { sešstūrainā kristāla režǵī } \\
\text { Two-dimensional nonlinear wave scattering in a } \\
\text { hexagonal crystal lattice }\end{array}$ \\
\hline $13.30-13.50$ & $\begin{array}{l}\text { Aleksandrs Jegorovs, } \\
\text { Valters Dzelme } \\
\text { Latvijas Universitāte }\end{array}$ & $\begin{array}{l}\text { MHD skaitlisko aprēḳinu eksperimentāla } \\
\text { validācija } \\
\text { Experimental validation of MHD numerical } \\
\text { simulations }\end{array}$ \\
\hline $13.50-14.10$ & $\begin{array}{l}\text { Elīna Kalniņa } \\
\text { Latvijas Universitāte }\end{array}$ & $\begin{array}{l}\text { Konkrētā sintaksē balstīta meklēšana uz } \\
\text { grafiem balstītās modelēšanas valodās } \\
\text { Concrete syntax-based find for graph-based } \\
\text { modeling languages }\end{array}$ \\
\hline $14.10-14.30$ & $\begin{array}{l}\text { Uldis Strautinšs, Laura Leja } \\
\text { Latvijas Universitāte }\end{array}$ & $\begin{array}{l}\text { Modelēšana ar diferenciālvienādojumiem uz } \\
\text { grafiem } \\
\text { Applications of differential equations on graphs }\end{array}$ \\
\hline
\end{tabular}




\begin{tabular}{|c|c|c|}
\hline $14.30-15.00$ & Diskusijas, kafijas pauze & \\
\hline $15.00-15.20$ & $\begin{array}{l}\text { Andrejs Sabanskis }{ }^{1} \text {, } \\
\text { Kaspars Dadzis' }^{2} \text {, Hans- } \\
\text { Joachim Rost }^{2} \text {, Robert } \\
\text { Menzel }^{2}, \text { Jānis Virbulis }^{1} \\
{ }^{1}{ }^{2} \text { atvijas Universitāte, } \\
{ }^{2} \text { Leibniz-Institut für } \\
\text { Kristallzüchtung }\end{array}$ & $\begin{array}{l}\text { Temperatūras un dislokāciju blīvuma } \\
\text { sadalījumu modelēšana Si kristāla sildīšanas } \\
\text { eksperimentā } \\
\text { Modelling of the temperature and dislocation } \\
\text { density distributions in the Si crystal heating } \\
\text { experiment }\end{array}$ \\
\hline $15.20-15.40$ & $\begin{array}{l}\text { Girts Zāógeris, Vadims } \\
\text { Geža } \\
\text { Latvijas Universitāte }\end{array}$ & $\begin{array}{l}\text { Virsmas viḷnu mehāniska radīšana šḳidrā } \\
\text { silīcijā } \\
\text { Wave generation on liquid silicon via mechanical } \\
\text { excitation }\end{array}$ \\
\hline $15.40-16.00$ & $\begin{array}{l}\text { Maksims Pogumirskis, } \\
\text { Tija Sīle, Jānis Hūns, Uldis } \\
\text { Bethers, Juris Seṇṇikovs } \\
\text { Latvijas Universitāte }\end{array}$ & $\begin{array}{l}\text { Meteoroloǵisko novērojumu datu } \\
\text { homogenizācija un tās pielietojumi klimatiskā } \\
\text { vēja ātruma samazināšanās izpētē } \\
\text { Homogenization of the meteorological } \\
\text { observation data and its applications in the } \\
\text { research of atmospheric stilling }\end{array}$ \\
\hline $16.00-16.20$ & $\begin{array}{l}\text { Mārtinš Klevs, Mihails } \\
\text { Birjukovs, Pēteris } \\
\text { Zvejnieks, Andris } \\
\text { Jakovičs } \\
\text { Latvijas Universitāte }\end{array}$ & $\begin{array}{l}\text { Sadalīšana dinamiskajās modās } \\
\text { magnetohidrodinamiskajai burbuḷu ḳēdes } \\
\text { plūsmai taisnstūrveida konteinerī } \\
\text { Dynamic mode decomposition of } \\
\text { magnetohydrodynamic bubble chain flow in a } \\
\text { rectangular vessel }\end{array}$ \\
\hline $16.20-16.40$ & $\begin{array}{l}\text { Vilnis Frišfelds } \\
\text { Latvijas Universitāte }\end{array}$ & $\begin{array}{l}\text { Augstas izšķirtspējas mikroplastikas } \\
\text { modelēšana Rigas jūras līcī } \\
\text { High resolution modelling of microplastics in Gulf } \\
\text { of Riga }\end{array}$ \\
\hline $16.40-17.00$ & $\begin{array}{l}\text { Andis Kalvāns, Gunta } \\
\text { Kalvāne } \\
\text { Latvijas Universitāte }\end{array}$ & $\begin{array}{l}\text { Heterogēnu fenoloǵisko datu analīze } \\
\text { Analysis of heterogenous multi-taxon } \\
\text { phenological data set }\end{array}$ \\
\hline 17.00 & \multicolumn{2}{|l|}{ Diskusijas, noslēgums } \\
\hline
\end{tabular}




\section{SATURS}

PROGRAMMA 3

Saturs 5

J. Bajārs, J.C. Eilbeck, B. Leimkuhler, Two-dimensional nonlinear wave scattering in a hexagonal crystal lattice. 6

A. Jegorovs, V. Dzelme, Experimental validation of MHD numerical simulations 7

E. Kalniņa, Concrete syntax-based find for graph-based modeling languages 8

U. Strautinš̌, L. Leja, Some applications of differential equations on graphs 10

A. Sabanskis, K. Dadzis, H.-J. Rost, R. Menzel, J.Virbulis, Modelling of the temperature and dislocation density distributions in the Si crystal heating experiment.....

G̦. Zāǵgeris, V. Geža, Wave generation on liquid silicon via mechanical excitation. 12

M. Pogumirskis, T. Sīle, J. Hūns, U. Bethers, J. Seṇņikovs, Homogenization of meteorological observation data and its applications in the research of atmospheric stilling

M. Klevs, M. Birjukovs, P. Zvejnieks'A. Jakovičs, Dynamic mode decomposition of MHD bubble chain flow

V. Frišfelds, High resolution modelling of microplastics in Gulf of Riga 16

A. Kalvāns, G. Kalvāne, Analysis of heterogenous multi-taxon phenological data set 17 


\section{TWO-DIMENSIONAL NONLINEAR WAVE SCATTERING IN A HEXAGONAL CRYSTAL LATTICE}

\section{Jānis Bajārs ${ }^{1}$, J.Chris Eilbeck ${ }^{2}$, Benedict Leimkuhler ${ }^{3}$}

1 University of Latvia, Jelgavas iela 3, Riga, Latvia,

${ }^{2}$ Heriot-Watt University, Edinburgh, EH14 4AS, United Kingdom

${ }^{3}$ The University of Edinburgh, James Clerk Maxwell Building, The King's Buildings, Mayfield Road, Edinburgh, EH9 3JZ, United Kingdom

E-mail: Janis.Bajars@lu.Iv

The nature of mysterious particle-like tracks in muscovite mica crystals have attracted much recent interest. The lines were first observed by Russell over 50 years ago, who suggested that they were caused by localized vibrational modes in the K-K layer of mica. This hypothesis has led to a number of simulations of breathers in model hexagonal lattices with on-site potentials. The surprising conclusion of these studies is that in similar models in 2D, localized single breathers can travel along the main crystal directions of the lattice with little attenuation or lateral spreading.

In this work we move beyond the case of single breathers by examining breather-breather collisions and describe, for the first time, the full 2D scattering of long-lived breathers in a model hexagonal lattice of atoms. We present evidence that breathers are remarkably robust to collisions, and scattering through some multiple of 60 degrees into another crystal lattice direction is frequently observed. In addition, we examine ensembles of initial conditions for breather-breather collisions, as illustrated by the figure bellow, to begin to understand how the relative angles and phases of the breathers affect their interactions.

The chosen system, representing an idealized model of mica, combines a Lennard-Jones interatomic potential with an "egg-box" harmonic potential well surface. We investigate the dependence of breather properties on the ratio of the well depths associated to the interaction and on-site potentials. High values of this ratio lead to large spatial displacements in adjacent chains of atoms and thus enhance the two dimensional character of the quasi-one-dimensional breather solutions. This effect is further investigated during breather-breather collisions by following the constrained energy density function in time for a set of randomly excited mobile breather solutions. Certain collisions lead to 60 degree scattering, and collisions of mobile and stationary breathers generate a rich variety of states.

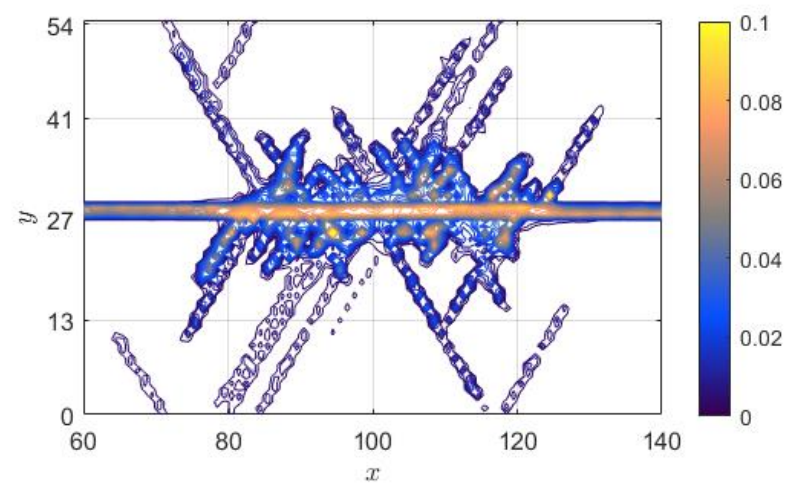

Fig. 1. Constrained energy density function averaged over 50 time snapshots and 2000 individual simulations of breather-breather collisions on adjacent chains of atoms.

\section{Acknowledgements:}

J. Bajārs acknowledges support from PostDocLatvia grant No. 1.1.1.2/VIAA/4/20/617. 


\title{
EXPERIMENTAL VALIDATION OF MHD NUMERICAL SIMULATIONS
}

\author{
Aleksandrs Jegorovs, Valters Dzelme \\ Institute of Numerical Modelling, University of Latvia, Jelgavas 3, Riga, Latvia \\ E-mail: Aleksandrs.Jegorovs@lu.lv
}

The goal of this study is to develop an automated magnetic field mapping device to measure field distribution around a rotating cylindrical permanent magnet. The device consists of a Teslameter, an oscilloscope for recording the signal, 3D printer motor to precisely move the probe and a computer. Part of this study involves developing a code that allows us to control and communicate the devices, as well as process the data.

The cylindrical magnet is part of an experimental setup where liquid metal flow is induced by its rotation. There are some discrepancies between our experiments and simulations regarding liquid metal free surface shape and deformation. Since rotating magnetic field is the main source of the flow, measuring the magnetic field will help finding possible sources for the disagreement and validating simulation results. 


\title{
CONCRETE SYNTAX-BASED FIND FOR GRAPH-BASED MODELING LANGUAGES
}

\author{
Elīna Kalniṇa \\ Institute of Mathematics and Computer Science, University of Latvia, Raina Blvd. 29, Riga, Latvia \\ E-mail: elina.kalnina@lumii.lv
}

We have got used to, that almost every software tool, e.g. text editors, programming tools etc. provide service of a find. However, the state of the art is not so good with graphical languages. We consider one specific type of graphical languages - graph-based languages. Typically there is some kind of textual find available in the editor of graph-based language. However, it is not enough with textual find for graph-based languages. Using textual find it is not possible to state that we want to look for provided text only in a specific property of a specific element type. It is also not possible to use the graph structure as a find query. In contrast, the concrete syntax-based find query is defined as a fragment of a diagram. Therefore, it is possible to state the required graph structure and content of property values.

Fig.1. illustrates simple concrete syntax based find query and corresponding textual query. A simple example of UML activity diagrams [1] is used here. On the left textual find is used and all instances of text "machine" are found. On the right, the concrete syntax-based find is used and text "machine" is found only in the performer property of action.

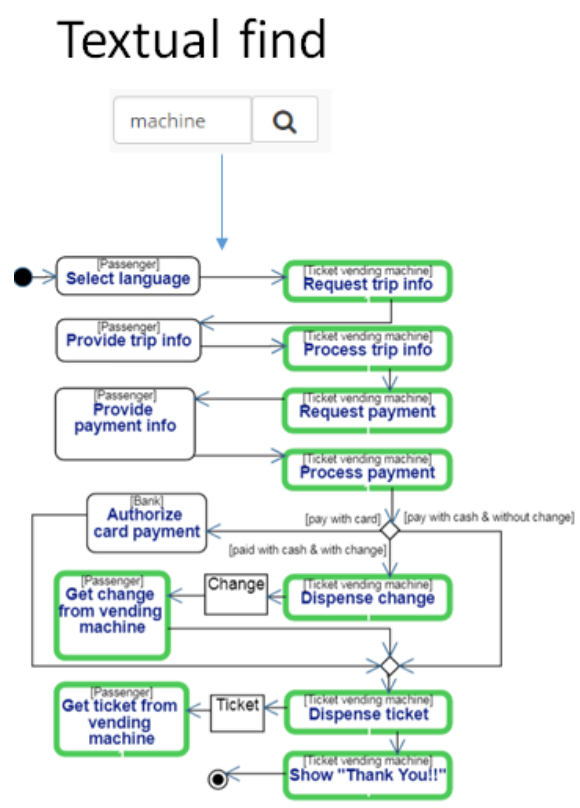

\section{Concrete syntax-based find}

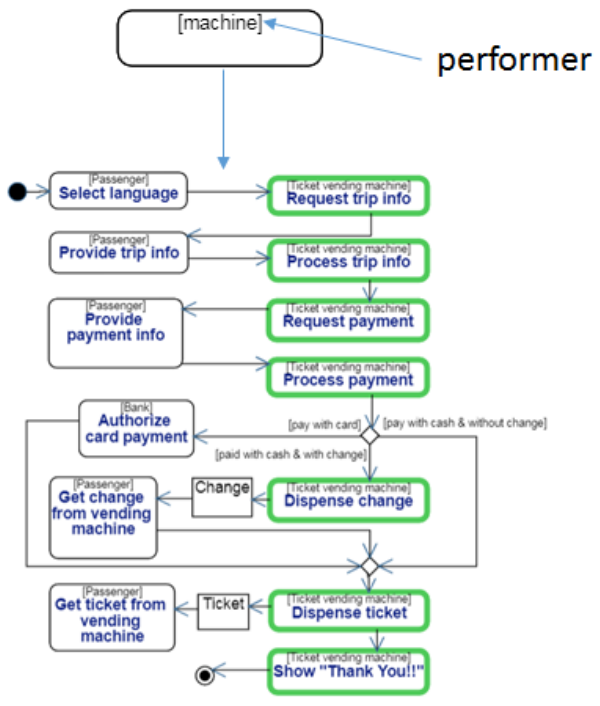

Fig. 1. Textual find versus concrete syntax based find

In the example, textual find resulted in two false-positive answers compared to concrete syntax-based find. However, if we have models with hundreds of diagrams, it may have a significant impact on the management of the models.

It is expensive to create editors for graph-based modelling languages. Therefore, there are multiple DSL (Domain-Specific Language) tool building frameworks facilitating the creation of tools for graph-based modelling languages, for example, Sirius, MetaEdit+, ajoo [2].

We propose to add concrete syntax-based as a service of a DSL tool definition framework. This way, the concrete syntax-based find is available in the editor of any graph-based language built with the DSL tool definition framework. 
We have implemented the approach in web-based framework ajoo [3]. Although, the encoding used by tools differ, the approach could be implemented in other DSL tools definition frameworks or other standalone modelling tools.

\section{References:}

[1] An OMG Unified Modeling Language Publication, OMG Unified Modeling Language (OMG UML), Version 2.5.1, formal/2017-12-05, https://www.omg.org/spec/UML/2.5.1/PDF

[2] Sprogis, A., "DSML Tool Building Platform in WEB," in Databases and Information Systems: 12th International Baltic Conference, DB\&IS 2016, Riga, Latvia, July 4-6, 2016. Proceedings, G. Arnicans, V. Arnicane, J. Borzovs, and L. Niedrite, Eds. Cham: Springer International Publishing, 2016, pp. 99-109.

[3] Kalnina, E., Concrete syntax-based find for graphical DSLs. In Proceedings of the 23rd ACM/IEEE International Conference on Model Driven Engineering Languages and Systems: Companion Proceedings (MODELS '20). Association for Computing Machinery, NY, USA, Article 11, 2020. 1-5. DOI:https://doi.org/10.1145/3417990.3422008

\section{Acknowledgements:}

The work has been supported by European Regional Development Fund within the project \#1.1.1.2/16///001, application \#1.1.1.2/VIAA/1/16/180 "Concrete Syntax Based Find for Graphical Domain Specific Languages". 


\section{SOME APPLICATIONS OF DIFFERENTIAL EQUATIONS ON GRAPHS}

\section{Uldis Strautiņš and Laura Leja}

Faculty of Physics, Mathematics and Optometry, University of Latvia, Jelgavas 3, Riga, Latvia

E-mail: Uldis.Strautins@lu.Iv

Traditionally differential equations on graphs (networks) - DEG - are defined as systems of ordinary differential equations, with one degree of freedom sitting at every vertex, and the edges signifying the interactions between the degrees of freedom. DEGs have a long history, e.g. the graph Laplacian was introduced by Kirchhoff (1847). Modern applications include studying consensus formation in multi-agent systems, diffusion on networks and synchronization phenomena. The well known method of lines for numerically solving nonstationary PDEs is another source of differential equations on graphs.

On digraphs, advection-diffusion-reaction equations can be introduced naturally. Besides being spatial discretizations of PDEs, such equations arise in modelling signal propagation in neural cells, disease spreading, image processing etc.

A more complicated class of DEGs arise naturally if we add a metric structure for the edges (creating a metric graph). Here a system of 1D PDEs on the edges coupled to a system of ODEs on the nodes arises naturally. This allows modelling complex flows on networks, such as gas flows on pipe networks etc.

In this talk we present a network model for thermal conversion of heterogeneous biomass granules for household and industrial heating applications. A heat and mass transfer model is developed. The granules are assumed to consist of particles of different materials (such as straw, wood, peat). In the network model the particles are represented as graph nodes, the interaction of the neighbouring particles sharing a common boundary as edges. Darcy law and Boussinesq approximation are used to model the flow of the gas (mixture of air and volatiles) through the porous granule. First order Arrhenius kinetics are assumed for the decomposition of the biomass. Simulations using Matlab illustrate the applicability of this model. 


\title{
MODELLING OF THE TEMPERATURE AND DISLOCATION DENSITY DISTRIBUTIONS IN THE SI CRYSTAL HEATING EXPERIMENT
}

\author{
Andrejs Sabanskis', Kaspars Dadzis², Hans-Joachim Rost ${ }^{2}$, Robert Menzel ${ }^{2}$, Jānis Virbulis ${ }^{1}$ \\ ${ }^{1}$ Institute of Numerical Modelling, University of Latvia, Jelgavas 3, Riga, Latvia \\ 2Leibniz-Institut für Kristallzüchtung, Max-Born-Str. 2, 12489 Berlin, Germany \\ E-mail: Andrejs.Sabanskis@lu.Iv
}

To better understand the dislocation generation in Si crystals, a model experiment was recently carried out by the researchers at the Leibniz-Institut für Kristallzüchtung, Berlin [1]. A silicon crystal in its as-grown state after a Float-Zone process was gradually inductively heated up again to $1200{ }^{\circ} \mathrm{C}$. In the present work a 3D numerical study of the experiment is performed, using the following simplifications: (i) the crystal is not moved; (ii) stationary temperature field is assumed.

Different inductor currents are applied to study its influence on the crystal surface temperature. The current needs to be adjusted to reach a specific target temperature measured in the experiment. An example of the calculated EM power density is plotted in Fig. 1a, where the effect of nonaxisymmetric inductor shape is clearly visible. The temperature field has been obtained (Fig.1b-c) and used in the thermal stress simulations depicted in Fig. 1d. Finally, the dislocation density and plastic deformations in the crystal are calculated using the Alexander-Haasen model; the results will be compared with the experiment [1] in further, more detailed, studies.
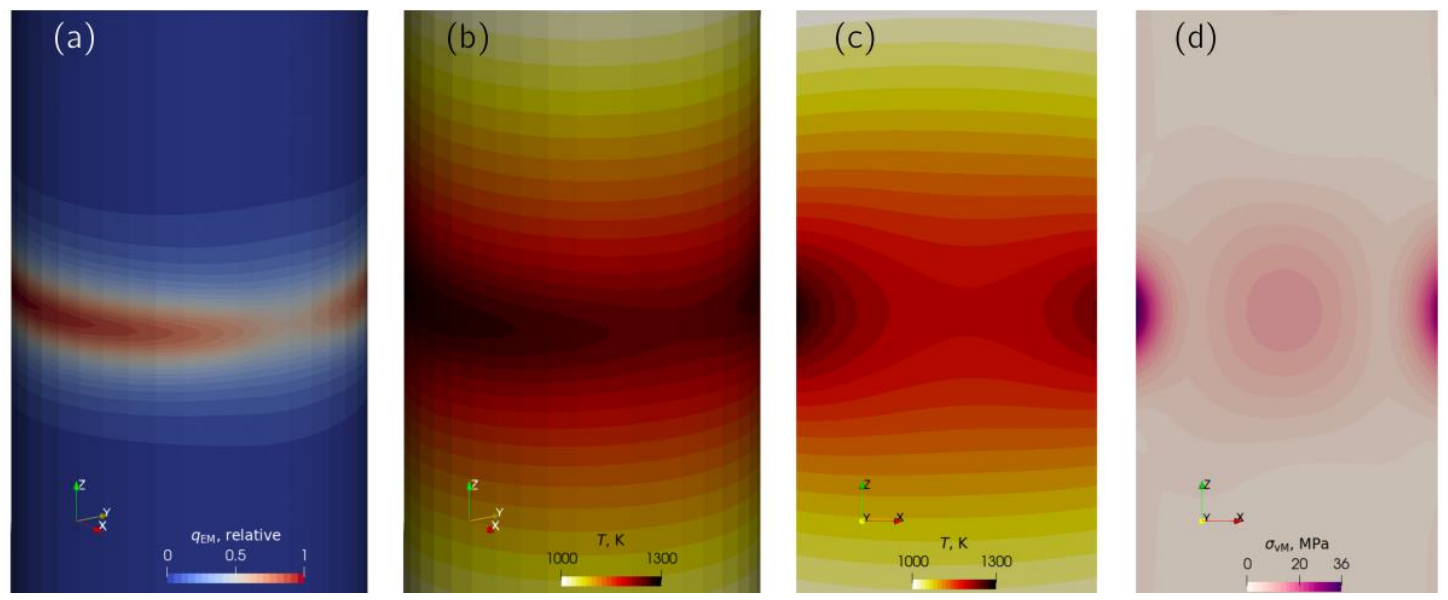

Fig. 1. Results of steady-state heat transfer and elastic stress simulations. (a) EM power density distribution on Si surface (relative units); (b) temperature distribution on Si surface with target temperature of $1000{ }^{\circ} \mathrm{C}$; (c) temperature in xz cross-section; (d) von Mises stress in xz cross-section. Crystal diameter is $20 \mathrm{~mm}$

\section{References:}

[1] Rost, H. J., Buchovska, I., Dadzis, K., Juda, U., Renner, M., \& Menzel, R., 2020. Thermally stimulated dislocation generation in silicon crystals grown by the Float-Zone method. Journal of Crystal Growth, 552, 125842.

\section{Acknowledgements:}

The present research has been supported by the PostDoc Latvia Project No. 1.1.1.2/VIAA/2/18/280. 


\title{
WAVE GENERATION ON LIQUID SILICON VIA MECHANICAL EXCITATION
}

\author{
G̦irts Zāǵgeris, Vadims Geža \\ Institute of Numerical Modelling, University of Latvia, Jelgavas 3, Riga, Latvia \\ E-mail: Girts.Zageris@lu.Iv
}

The production of solar-grade purity silicon requires metallurgical procedures to remove impurities, which are often carried out for molten silicon. It is known that the rate of impurity removal is proportional to the surface are of the molten silicon via which these impurities can be evacuated. One method to increase this surface area is to generate surface waves, and one of the simplest methods is to generate waves mechanically. In this study, the response of the silicon melt under mechanical excitation is studies.

This study was carried out numerically in 2D with a square container partially filled with liquid silicon, while the gas phase was filled with argon. The container with the melt underwent a harmonic motion:

$$
x(t)=A \sin \omega t
$$

Here, there parameters $A$ and $\omega$ can be freely set, and a third important parameter - the ratio of the height of the melt and the height of the tank, $\mathrm{h} / \mathrm{H}$, can also be freely set. The effects of various amplitudes, frequencies and height ratios were studied to determine viable ranges of operation for the purification process, which requires no violent sloshing to occur.

It was determined that three regimes of waves can be observed - firstly, barely any wave excitation that originates at the walls of the tank and quickly damps out due to viscosity, secondly, fully realized and chaotic waves that can travel from the wall to the middle of the tank, and thirdly, violent sloshing, which is undesirable for the application in question. These regimes can be obtained both by varying the oscillation amplitude and frequency. In no case could the surface area be increased more than $10 \%$ before violent sloshing began to take place. A range of amplitude and frequency values were found that result in the optimal regime of sloshing where waves are created but they do not break and being to slosh violently. The mechanical power required to supply these values was calculated and it was found that, depending on the combination of the chosen parameters, the required power can differ by an order of magnitude, thus a shrewd choice of parameters is required. It is therefore important to note that data show that surface area grows faster with increasing amplitude than it does with increasing frequency. Finally, it was determined that at higher $\mathrm{h} / \mathrm{H}$ ratios the onset of the violent sloshing is quicker.

It must be noted that these findings are presently limited to a square tank, as every different geometry of a tank will have different natural frequencies of sloshing. Nevertheless, since the study is done in terms of natural frequencies, it may be of some use for other cases as well. Initial results concerning a 3D cylinder show that behavior that was expected from the results in this study exhibit themselves in this new situation as well. 


\title{
HOMOGENIZATION OF METEOROLOGICAL OBSERVATION DATA AND ITS APPLICATIONS IN THE RESEARCH OF ATMOSPHERIC STILLING
}

\author{
Maksims Pogumirskis, Tija Sīle, Jānis Hūns, Uldis Bethers, Juris Seṇṇikovs \\ Institute of Numerical Modelling, University of Latvia, Jelgavas 3, Riga, Latvia \\ E-mail: Maksims.Pogumirskis@lu.Iv
}

A decrease of the near surface climatological wind speed had been observed over the last decades. This phenomenon is known as the global terrestrial stilling. Decrease of the wind speed raises concerns about wind energy production and air quality in the urban areas. Surface evaporation rate is affected by the wind speed, influencing water demand for the irrigation of farmlands.

Causes of the atmosphere stilling are still unclear. One of the possible explanations is the weakening of the large-scale pressure gradients and global atmospheric circulations. A different possible cause is the increase of the friction force. Both surface friction and turbulent friction changes can be used to explain the stilling. Increased surface friction can be caused by the urbanization and increased forest cover. Turbulent friction ensures the vertical momentum transport in the boundary layer, and lower turbulent friction could lead to lower surface wind speeds.

However, a recent study (Zeng 2019) published in the "Nature" journal reported global reversal of the atmosphere stilling start from 2010, i.e., climatological increase of wind speed and suggested that changes in the wind speed are due to the multidecadal atmosphere oscillations.

The initial goal of our study was to quantify the atmosphere stilling in different datasets in order to elucidate links with the possible causes. One of the datasets was surface wind speed observation data for the Europe (768 stations) between 1980 and 2019 derived from the ISD dataset. Data homogenization addresses possible effects of the station relocation and instrumental change comparing wind speed series between adjacent stations. However, this procedure struggles to detect issues that occur in many stations close to each other at the same time, which is common for the stations in the same country. R package "Climatol" was used in this study.

Further investigation showed that frequency of the calm conditions in Europe suddenly decreased from $8 \%$ in 2012 to $3 \%$ in 2014 , while frequency of slow winds $(<1.5 \mathrm{~m} / \mathrm{s})$ increased. Meanwhile frequency of the moderate and fast winds had a uniform trend during the entire period. A possible explanation for the sudden change is a mass replacement of anemometers in Europe. Newer anemometers can more consistently detect weak winds, which were often reported as calm conditions by older anemometers. To address this issue, another set of wind speed series was derived, using only observations that exceeded $1.5 \mathrm{~m} / \mathrm{s}$.

Wind speed series derived from the complete dataset showed decrease of the wind speed in Europe between 1980 and 2010 and increase since 2010. Meanwhile, wind speed series derived using only measurements greater than $1.5 \mathrm{~m} / \mathrm{s}$, showed negative trend during the entire period of interest. No reversal of the atmosphere stilling in 2010 appeared. That suggests that reversal in the atmosphere stilling in Europe is due to instrumental change and not due to the multidecadal atmosphere oscillations.

\section{References:}

[1] Zeng, Z., Ziegler, A.D., Searchinger, T. et al., 2019. "A reversal in global terrestrial stilling and its implications for wind energy production." Nat. Clim. Chang. 979-985. 


\title{
DYNAMIC MODE DECOMPOSITION OF MHD BUBBLE CHAIN FLOW
}

\author{
Mārtiņš Klevs, Mihails Birjukovs, Pēteris Zvejnieks and Andris Jakovičs \\ Institute of Numerical Modelling, University of Latvia, Jelgavas 3, Riga, Latvia \\ E-mail: Martins.Klevs@lu.Iv
}

Bubble flow in liquid metal occurs in industrial processes such as metal stirring, purification, continuous casting, etc. These processes can be controlled and stabilized via applied magnetic field (MF). Bubble flow exhibits complex collective dynamics, making it hard to predict, especially with applied MF. Some aspects of magnetohydrodynamic (MHD) bubble flow are still not fully understood, preventing accurate modelling with Euler-Euler and Lagrangian models. Experimental and numerical data from explicit simulations are required to understand how MF orientation/intensity and gas flow rate affect bubble flow. Therefore, downscaled systems with model liquid metals and gases are used. Bubble trajectories are mostly controlled by wake flow dynamics and are influenced by bubble shape oscillations, which also determines bubble chain flow (BCF) characteristics. BCF is a simplified representation of industrially relevant processes, but despite the simplicity exhibits complex quasi periodic patterns and with a wide range of time scales. It is therefore of interest to perform a combination of dimensionality reduction and flow mode analysis to see exactly how MF affects wake flow patterns, pressure distribution beneath bubbles, shape oscillation wavelengths and liquid metal flow surrounding the bubble chain.

To analyze the model system wherein bubbles are injected at the bottom of a rectangular vessel and ascend to the top through liquid gallium, dynamic mode decomposition (DMD) is applied. We have developed an algorithm in Python based on the higher order DMD scheme combined with the MOSES algorithm for streaming singular value decomposition. Our code is resilient to input noise and very memory efficient, enabling quick processing of high-resolution data on a desktop PC. BCF simulations were performed without and with static horizontal MF using OpenFOAM. After BCF reached a quasi-periodic regime, system states were sampled for 4 seconds (400 states). We computed the first 20 modes for the velocity field in the gallium vessel. To compute bubble wake flow, pressure field and volume fraction field modes for bubbles, we used an in-house tracing algorithm to compute the relative velocity field for bubbles. Preliminary results are showcased in Fig. 1-3.

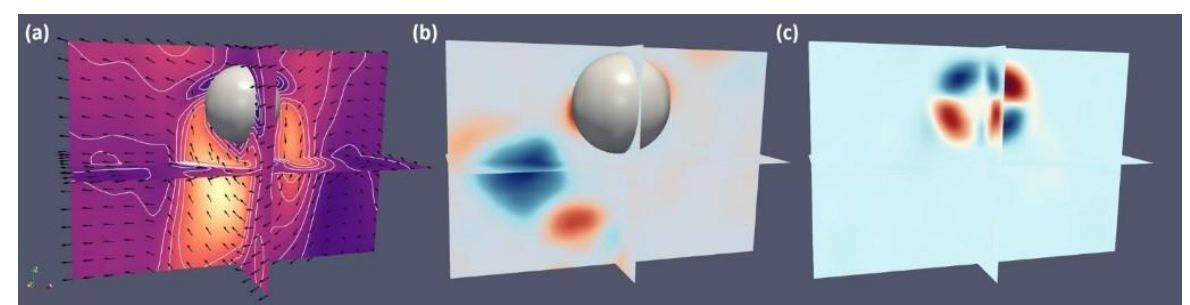

Fig. 1. Example DMD modes without applied MF, bubble reference frame: (a) velocity, (b) pressure and (c) volume fraction fields. Silver spheres are DMD masks. (a,b) are vortex shedding modes and (c) represents shape oscillations

With this method, as seen in Fig. 3, one can immediately quantify the effects of applied MF: changes in the mode frequency spectrum can be identified and it can be determined which modes are damped by the induced Lorentz force. Combining this with volumetric mode representations as in Fig. 1 and 2, an in-depth quantitative analysis of the effects of MF orientation/intensity and gas flow rate can be performed for the parameter space (Reynolds/Eötvös/Stuart numbers) of the model system. This in turn can help derive effective parameters for approximate numerical models of bubble flow in industrial installations. 


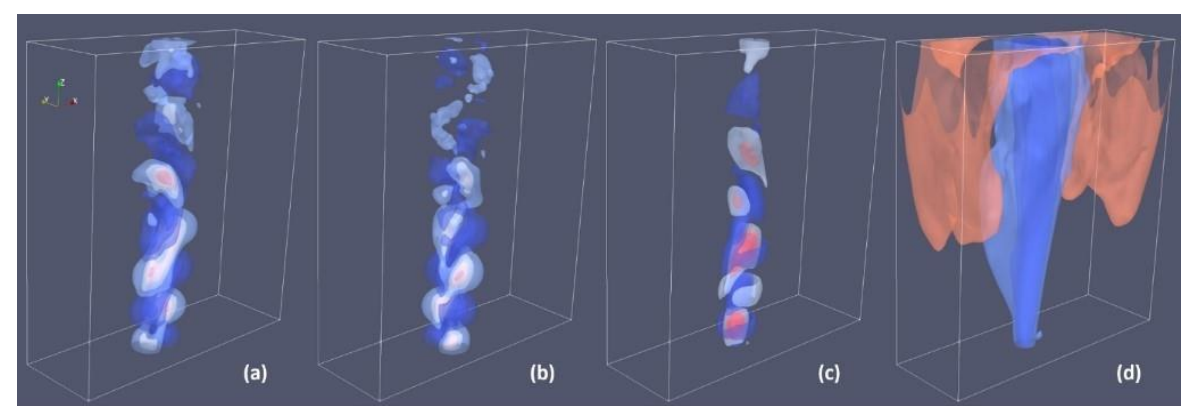

Fig. 2. Example DMD modes without applied MF, vessel reference frame: (a-c) are the $x, y$ and $z$ velocity components of a mode associated with vortex shedding within the bubble chain and (d) is the average velocity field mode ( $z$ component) showing the bubble chain envelope (upward flow) and side vortices (downward flow)

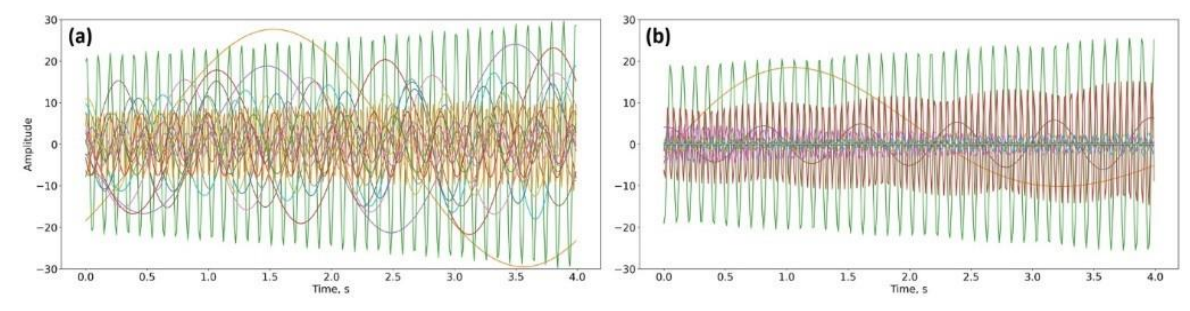

Fig. 3. Velocity field mode amplitudes in the vessel reference frame over time (a) without and (b) with applied MF

\section{Acknowledgements:}

The authors acknowledge the support due to the ERDF project "Development of numerical modelling approaches to study complex multiphysical interactions in electromagnetic liquid metal technologies" (No. 1.1.1.1/18/A/108). 


\title{
HIGH RESOLUTION MODELLING OF MICROPLASTICS IN GULF OF RIGA
}

\author{
Vilnis Frišfelds \\ Institute of Numerical Modelling, University of Latvia, Jelgavas 3, Riga, Latvia \\ E-mail: frishfelds@latnet.Iv
}

More and more plastic waste have been ending up in the sea during the previous decades. The small size of the microplastic particles does not allow wastewater treatment systems to retain them. These small particles overgrow with the biosphere, causing the particles to become heavier and later settle to the seabed.

The behavior of 3 different sizes of microplastics in the Baltic Sea and the Gulf of Riga is modeled using the HIROMB BOOS 3-dimensional ocean model. The resolution of the model is $1 / 4$ nautical mile in the Gulf of Riga and 1/20 nautical mile in the Daugava and Lielupe river mouth. The vertical resolution of the model is $1 \mathrm{~m}$.

The model shows the behavior of different fractions in the Gulf of Riga depending on the season. The area of the Gulf of Riga is nested in the Baltic Sea model, allowing the study of microplastic transport through the Irbe Strait. 


\title{
ANALYSIS OF HETEROGENOUS MULTI-TAXON PHENOLOGICAL DATA SET
}

\author{
Andis Kalvāns, Gunta Kalvāne \\ Faculty of Geography and Earth Sciences, University of Latvia, Jelgavas 1, Riga, Latvia \\ E-mail: Andis.Kalvans@lu.Iv
}

Phenology is the study of seasonal phenomena in nature as flowering, leafing, bird's migration etc. The prime interest of phenological research is timing of phenological phases and their interactions. We examine a data set of nearly 47 thousand of phenological observations in Latvia from 1970 to 2018. The data set comprises observations of 159 phenological phases spanning across eight taxonomical groups, as well as abiotic phenomena such as the first snow, last spring frost and agrarian activities (sowing, harvesting) in Latvia.

Despite the large volume observations, the longest continuous observation series are only 30 years, and much less in most of cases. We set out to perform multivariate statistical analysis of this data set. However, patch nature of observations hampered the analysis. Therefore, we constructed a pair-vice cross-correlation matrix for 66 phenological phases having at least 200 overlapping observations with all other phase included in the analysis. Further we used this matric as an input to hierarchical cluster analysis.

As a result, we identified 7 clusters with phenological phases with corelated onset timing, expressed as day since beginning of year. The cluster \#1 is a grouping of early-summer phases, mostly flowering and fruiting of woody plants and domestic berries. The cluster \#2 combines the earliest spring phases - the first flowering of woody species. The cluster \#3 is the grouping of latespring phases, mostly flowering. The cluster \#4 is an indistinctive grouping of agrarian activities and abiotic occurrences. The cluster \#5 represents the first spring sighting of migratory birds. While the clusters \#6 and \#7 that were most distinct from the other clusters (highest branching level) grouping respectively late autumn phases (such as first snow and departure of wild geese and leaf senescence.

Furthermore, we calculated an aggregated index for yearly timing of phenological phase as a mean normalized phase timing across clusters. The first three clusters show dramatic advance (early onset) starting from 1989. Visually the advance can be interpreted as shift in the system state or breaking point around this time. However, we did not attempt to test it mathematically. Clusters represent summer phases show earlier onset timing as well, however, less extent compared to spring. The late autumn phases have a positive trend - latter onset dates. However, cluster grouping the leaf sentence do not have a clear trend suggesting that the phenomena either was not affected by climatic warming or high uncertainty of observations mask any background trend.

These results were recently published by International Journal of Biometeorology (Kalvāne and Kalvāns, 2021). Kalvāne, G. and Kalvāns, A.: Phenological trends of multi-taxonomic groups in Latvia, 1970-2018, Int. J. Biometeorol., 2021. doi:https://doi.org/10.1007/s00484-020-02068-8, 2021.

\section{Acknowledgements:}

This study was carried out within the framework of the Impact of Climate Change on Phytophenological Phases and Related Risks in the Baltic Region (No. 1.1.1.2/VIAA/2/18/265) and Groundwater and soil water regime under climate change (No. 1.1.1.2/VIAA/3/19/524) ERDF projects. 